\title{
Instructional Methods Applied by Visually Impaired Teachers in Teaching Students with Intellectual Disability
}

\author{
Oktaviana Saputri ${ }^{1}$, Hakiman $^{2}$, Suluri ${ }^{3}$ \\ 1,2,3 Institut Agama Islam Negeri Surakarta, Indonesia, \\ hakiman.iman@gmail.com ${ }^{1}$
}

\begin{tabular}{ll}
\hline \hline & Abstract \\
\hline Keywords: & This study aims at investigating the instructional methods applied \\
Methods; & by the Islamic religious education teacher with visual impairment \\
Impaired & in teaching the students with mild and moderate intellectual \\
Teachers; & disability. This is a qualitative descriptive research. The data were \\
Intellectual & collected through in-depth interview, observation and \\
Disability. & documentation techniques. Triangulation is used as the technique \\
& to facilitate the validation of data, including the methods, sources \\
& and theories. Meanwhile, the data analysis technique includes data \\
& reduction, data display and conclusion drawing. The findings of \\
& this study reveal that in the learning activities, the visual impaired \\
& teacher uses several methods, including lecture method, discussion \\
& method, demonstration method, and assignment method on \\
& students with mild intellectual disability. Meanwhile, the methods \\
& used on students with moderate intellectual disability include \\
& lecture method, discussion method, storytelling method, \\
& demonstration method and drilling method. The process is \\
& equipped with learning media, including audio-visual media, \\
& screen reader technology, printouts in which self-helped students \\
& also provide assistance to the teacher. This study describes the \\
& learning process of Islamic religious education conducted by \\
& visually impaired teacher and it is expected that the findings will \\
provide insight and input for teachers in teaching students with \\
intellectual disabilities both in schools for special needs and similar \\
inclusive schools.
\end{tabular}

Abstrak:

Kata Kunci:
Metode; Guru dengan gangguan penglihatan; cacat intelektual.

Penelitian ini bertujuan untuk menginvestigasi metode
instruksional yang diterapkan oleh guru Pendidikan Agama Islam
dengan gangguan penglihatan dalam mengajar siswa yang
memiliki cacat intelektual ringan dan sedang. Penelitian ini bersifat
deskriptif kualitatif. Data dikumpulkan melalui interview secara
mendalam, observasi dan tehnik dokumentasi. Triangulasi
digunakan untuk memfasilitasi validasi data, termasuk triangulasi
metode, sumber dan teori. Sementara itu, tehnik analisis data


menggunakan tahapan mereduksi data, menyajikan data dan pengambilan kesimpulan. Hasil dari penelitian ini menemukan bahwa dalam kegiatan pembelajaran guru dengan gangguan penglihatan menggunakan beberapa metode seperti metode ceramah, diskusi, demonstrasi, dan penugasan pada siswa dengan cacat intelektual ringan dan sedang. Sementara metode yang digunakan untuk siswa dengan cacat intelektual sedang termasuk metode ceramah, diskusi, story-telling, demonstrasi dan latihan. Proses pembelajaran dilengkapi dengan media, termasuk media audio-visual, tehnologi screen reader, printout dimana siswa yang bisa mengatasi dirinya sendiri juga membantu guru. Penelitian ini mendiskripsikan proses pembelajaran Pendidikan Agama Islam yang diselenggarakan oleh guru dengan gangguan penglihatan dan diharapkan temuan penelitian ini menghgasilkan sebuah pandangan dan masukan kepada guru- guru dalam mengajar siswa dengan ketidak mapuan intelektual baik di sekolah berkebutuhan khusus atau sekolah inklusi.

\begin{tabular}{cc}
\hline \hline \multicolumn{2}{c}{ Received : 12 Maret 2020; Revised: 05 Juni 2020; Accepted: 14 Juni 2020 } \\
\hline $\begin{array}{c}\text { (C) Tadris Jurnal Pendidikan Islam } \\
\text { Institut Agama Islam Negeri Madura, Indonesia }\end{array}$ & This is an open access article under the CC-BY-NC license \\
\hline \hline
\end{tabular}

\section{Introduction}

As one of the basic needs, education becomes a necessity for every human in order to build a decent life. Therefore, the state has a responsibility to provide quality educational services for all. Furthermore, education is an inclusive one hence it is also offered for those with special needs. Law No. 20 of 2003 concerning the National Education System stipulates the provision of education with special services for children with special needs.

Students with intellectual disability are generally indicated by limited intelligence and social inadequacy. This limitation is also characterized by significantly lower intellectual functioning than average in which the abilities of Students with intellectual disability vary from one another. In the context of learning service, these different abilities become an issue since they imply the heterogeneous needs of service. Essentially, every student requires certain educational services, in terms of curriculum and instructional methods. ${ }^{1}$

Many efforts are emphasized on the strategies to eliminate the physical and mental limitations undergone by children with special needs. The goal is to explore and develop their personalities so as they can live normally and interact with the community without any discrimination. Therefore, the efforts entail the availability of educational services with special needs.

Due to their special needs, Students with intellectual disability should receive spiritual guidance according to their capacities. Islamic religious education for these students must be delivered practically and attractively hence they will be able to acquire the materials optimally. It is expected that with comprehensive understanding of religious teachings and values, their daily attitudes and behaviors will be imbued by these teaching and values.

\footnotetext{
${ }^{1}$ Kemis and Ati Rosnawati, Pendidikan Anak Berkebutuhan Khusus Tunagrahita (Luxima Metro Media, 2013), 1-2.
} 
In fact, Religious Education is not solely a compulsory subject for students in general, but also for those with special needs in order to have a decent life. According to Mardiyanti and Haryanthi, despite the obstacles faced by students with special needs, Islamic Religious Education is a must for them. Therefore, supports from peers, society and parents are essentially required. ${ }^{2}$

Similarly, the existence of teachers with visually impairment cannot be ignored. Despite of their limitations, they have the capacities to teach students with special needs by using suitable instructional methods, including in teaching Islamic religious education. Moreover, in the learning activities, these teachers will not be assisted by any colleague but by their students. Yet in reality, both teachers and students who have special needs are able to maintain constructive learning process.

Meria, reveals that the majority of teachers apply lecture method in conveying materials while for practices, they tend to use role plays approach. Lecture, demonstration and role plays are acceptable instructional methods for Students with intellectual disability. ${ }^{3}$ However, the implementation of such methods must be equipped with audio-visual media and other props. These media are intended to provide more understanding. Meanwhile, Takeshi claims that in teaching students with special needs, teachers can focus on real experiences particularly on practical and specific activities of their daily lives. ${ }^{4}$

The problems that may arise from learning process-which involves Students with intellectual disability and visually impaired teacher-are related to student's abilities in understanding the material and teacher's methods in conveying the material. Therefore, the present study aims to explain the instructional methods implemented by visually impaired teachers in conveying Islamic Religious subject to Students with intellectual disability.

In Arabic, the word for method is called Tariqa, which means the strategic steps prepared to perform a task. ${ }^{5}$ In the context of education, method must be addressed to build the character and personality of students who engage in effective and efficient learning activities. Instructional methods are fundamental to optimize the learning outcomes. Essentially, methods are the tool used to construct effective and efficient learning processes.

Furthermore, the instructional methods are the strategies carried out appropriately and suitably to convey a material in order to achieve effective and efficient learning objectives based on the expectation. ${ }^{6}$ Therefore, during each meeting, teachers do not randomly apply instructional methods but they have to be selected continuously and thoroughly according to specific instructional objectives. The goal of this formulation is to facilitate students in achieving the expected learning outcomes.

Various instructional methods have been devised to ensure both teachers and students successfully carry out teaching-learning activities, as well as to

\footnotetext{
${ }^{2} \mathrm{~N}$ Mardiyanti and Luh Putu Suta Haryanthi, "Challenges on learning Islam among deaf Muslim in an Indonesian context: Deaf teachers perspective.," International Medical Journal Malaysia, no. specialissue1 (2016): 17-21.

3 Azizah Meria, "Model Pembelajaran Agama Islam bagi Anak Tunagrahita di SDLBYPPLB Padang Sumatra Barat,” Tsaqafah 11, no. 2 (2015): 54-62, https://doi.org/10.21111/tsaqafah.v11i2.273.

${ }^{4}$ Takeshi Chikurinji, "A Study on Teaching Schoolchildren with Intellectual Disability," NISE Bulletin, November 2008, 9 edition.

${ }^{5}$ Ramayulis, Metodologi Pendidikan Agama Islam, R.J. Offset. ed (Jakarta: Kalam Mulia, 2014), 23.

${ }^{6}$ Ismail, Strategi Pembelajaran Agama Islam Berbasis PAIKEM (Semarang: Rasail Media Group, 2012), 13-14.
} 
achieve the expected learning outcomes and support the quality of education. The basic principle of instructional methods includes their tactical, technical and practical attributes for optimal learning. These instructional methods are defined as strategies or measures implemented in the learning process in order to achieve effective and efficient learning objectives as planned in the syllabus of subjects.

In the learning process, instructional methods have several objectives, namely: 1) to help students in acquiring knowledge, information, experience, skills and attitudes, particularly correct scientific thinking skills, as well as to build the fondness in knowledge, explore, reveal and enjoy in pursuing knowledge; 2) to habituate students in memorizing, understanding, critical thinking, having proper attention, examining, being attentive, patient, and careful in studying, as well as having honest, genuine, and independent opinions; 3) to facilitate students in their learning process so they are able to achieve as many desirable goals as possible, as well as to save the required energy and time to achieve them; 4) to create a learning environment with the basis of trustworthiness and respect among teachers and students and good relations between them.

Instructional methods have a key role in learning process. Methods are the guidance for achieving learning objectives. Their role will be noticeable only when teachers select appropriate methods. The methods are including: 1) Lecture Method, 2) Discussion Method, 3) Demonstration Method, 4) Storytelling Method, 5) Drill Method, 6) Assignment Method, and 7) Sociodrama Method. ${ }^{7}$

For children with special needs, Islamic Religious Education can be conveyed through lectures, discussion and practice assisted by physical cues. ${ }^{8}$ Meanwhile Kumala and Sormin, explain the methods of lecture, demonstration, questions and answers, storytelling, and drill can be also be useful. ${ }^{9}$ In fact, various methods have been developed for teaching students with intellectual disability, particularly for the subject of Islamic religious education.

Islamic religious education is one of the compulsory subjects for Muslim students in completing their education at a certain level. ${ }^{10}$ In Indonesia, this subject is included in the national education system and designed specifically for Muslim students to enhance their understanding in Islamic teachings. This subject is an inseparable part in school curriculum and is perceived as a means to attain one aspect of the objectives of the school.

In general, Islamic Religious Education is devised from the basic teachings of Islam. The basis of these teachings is the Qur'an and Hadith that have been studied and explicated thoroughly by Islamic scholars through the process of ijtihad (independent reasoning). Basically, Islamic Religious Education is an endeavor directed at the character building of students based on the Islamic teachings.

Based on the explanation, Islamic Religious Education is defined as a subject with the basis of Islamic teachings that is aimed to guide students for

\footnotetext{
${ }^{7}$ Metodologi Pendidikan Agama Islam, 16.

${ }^{8}$ M Maftuhin and Januar Fuad, "Pembelajaran Pendidikan Agama Islam Pada Anak Berkebutuhan Khusus.," Jurnal An-Nafs: Kajian Penelitian Psikologi 03, no. 01 (2018): 76-90.

${ }^{9}$ Intan Kumalasari and Darliana Sormin, "Metode Pembelajaran Pendidikan Agama Islam Pada Anak Tunagrahita Di SLB C Muzdalifah Medan," Tazkir: JUrnal Penelitian LImuIlmu Sosial Dan Keislaman 05, no. 01 (2019): 16-19.

${ }^{10}$ Adi Novan Wiyani, Pendidikan Karakter berbasis Iman dan Taqwa (Yogyakarta: Teras, 2012), 145.
} 
having certain attitudes and behaviors in order to maintain a good relationship with God, others, themselves and the nature.

The objectives of Islamic Religious Education areto inculcate and enhance students' devotion, through the provision and enrichment of knowledge, appreciation, practice and experience related to Islamic teachings, hence they become pious persons who are eager in fortifying their faith and devotion to Allah SWT, possessing virtue in terms of personal, community, national and state life, as well as having the competence to continue at higher educational levels. ${ }^{11}$

The functions of Islamic Religious Education include: 1) to instill Islamic teachings and values in students, 2) to enhance faith and devotion to Allah (SWT) and character building, 3) to lead the students to adjust their mentality to the environment, 4) to practice Islamic teachings and values in reality, 5) to prevent students from negative impacts of foreign cultures, 6) to provide a general, systematic and functional religious science, 7) to facilitate and prepare students in exploring religious education for higher education institutions. ${ }^{12}$

The materials of Islamic Religious Education are generally divided into four aspects, namely: the Qur'an and Hadith, Aqeedah, Morals and Fiqh. These aspects emphasize the balance, harmony and equilibrium between Allah (SWT), humans and the nature.

The provision of religious education for students with intellectual disability must be accompanied by competencies of Islamic Religious Education teachers. The lack of insight and expertise of Islamic Religious Education teachers, particularly in dealing with students with special needs, has been a serious issue. It highlights the necessity for teachers in mastering the skills in dealing with students with intellectual disability.

Teachers play a great role in the mindset and character building of students through education, leading to their vital position in learning activities. In addition to provide certain materials, they are required to convey them effectively hence the students are able to understand them easily.

Visually impairment is a condition when a person has severe or loss of vision due to damage or dysfunction. ${ }^{13}$ A person with blindness or total loss of vision usually functions her/his hearing ability to communicate with others. As a consequence, they are more sensitive in identifying sounds or voices.

Likewise, Mutmainnah explains that people with visual impairment are those who have no sight or poor sight. Based on its severity, they can be classified into total blindness and low vision. Meanwhile, based on the nature, it can be distinguished into 'being born blind' and 'becoming blind'. Basically, visual impairment is defined asa condition of a person who has limitations in one of the senses, namely the vision, caused by damage or dysfunction. ${ }^{14}$ Therefore, person with visual impairment make use of other senses such as touch, smell and hearing.

\footnotetext{
${ }^{11}$ khosiah siti Rachmah and Rika Sa'diyah, "Strategi Pembelajaran PAI Pada Peserta Didik Tuna Grahita Sekolah Dasar Kelas Awal Di Sekolah Dasar Luar Biasa (SDLB) Pembina Tingkat I Cilandak Lebak- Bulus Jakarta Selatan," JUrnal Pandidikan Islam 2, no. 01 (2017): 34-35.

${ }^{12}$ Rachmah and Sa'diyah, 34-35.

${ }^{13}$ Sulthon, "Pola Keberagamaan Kaum Tuna Netra Dan Dampak Psikologis Terhadap Penerimaan Diri," Quality 4, no. 01 (2016): 50.

${ }^{14}$ Rahmita Nurul Mutmainnah, "Pemahaman Siswa Tunanetra (Buta Total Sejak Lahir Dan Sejak Waktu Tertentu) Terhadap Bangun Datar Segitiga," Jurnal Pendidikan Matematika dan Matematika 01, no. 01 (2015): 20.
} 
Effendi classifies the degree of visual impairment into three groups, namely: 1) Visual impaired persons with the chances of being corrected with appropriate treatment, cure or certain optical devices. Moreover, they are not identified as blind since they can use the visual function properly; 2) Visual impaired persons who still experience difficulties in carrying out daily activities despite of certain treatment, cure or optical devices. They are classified in low vision group since they are able to distinguish shadows; 3) Visual impaired persons with no chances of being corrected with any treatment, cure or optical devices since they are totally sightless. ${ }^{15}$

Technically, visual impairment is caused by various factors, namely internal and external factors. The internal factors are closely related to the condition of the fetus during pregnancy. They include inherited genetic trait, maternal psychological condition, malnutrition, drug/toxicity, and so on. Meanwhile, external factors are related to the events after the birth, e.g., accidents, syphilis infection on newborn's eyes, medical tools during delivery that damage newborn's nervous system, malnourished or vitamin deficiency, exposure to a toxic, trachoma, high fever, eyes inflammation, and bacteria or viruses. ${ }^{16}$

In fact, there are Islamic Religious Education teachers with visual impairment, yet they enthusiastically carry out their duties as teacher. With their exceptional sense of touch and instinct, they possess distinctive instructional methods to be applied in the classroom.

Students with intellectual disability are students who face significant challenges and underdeveloped intellectual and mental growth below average thus they have difficulties in completing certain tasks. As a result, they need special education services. In general, they have less than average IQ and encounter behavior and adjustment problems. Commonly, these take place during their developmental stage. ${ }^{17}$

Mental retardation is characterized by significant limitations both in intellectual functioning and in adaptive behavior as expressed in conceptual, social, and practical adaptive skills. ${ }^{18}$ In this context, such limitations are recognized before the children reaching 18 years of age. Children with mental retardation are characterized by decreased intelligence and deficits in adaptive behavior.

In general, intellectual disability is also known as general learning disability, mentally handicap, and mental retardation. Within the society, children with intellectual disability are identified from their significant intellectual impairment in which they need a special educational service in order to develop their potentials. ${ }^{19}$

Nevertheless, the presence of children with intellectual disability is often misinterpreted as a sort of ailment, which is absolutely false. In fact, this condition is not an illness but a generalized neuro-developmetal disorder that is

\footnotetext{
${ }^{15}$ Muhammad Effendi, Pengantar Psikopedagogik Anak Berkelainan (Yogyakarta: Ombak, 2006), 28.

${ }^{16}$ Sujhati Somantri, Psikologi Anak Luar Biasa (Bandung: Refika Aditama, 2012), 114 15.

${ }^{17}$ Mardhiyah, Siti Dawiyath, and Jasminto, "Identifikasi anak berkebutuhan khusus dan strategi pembelajarannya," Al-Ta'dib 3, no. 01 (2013): 60.

${ }^{18}$ Hwee kok Noel Chea and Ee Meng wong, "From Mental Retardation to Intellectual Disability: A Proposed Educological Framework for Teaching Students with Intellectual Disabilities in Singapore," Academic Research International 5, no. 03 (2014): 150.

${ }^{19}$ Amin Muhammad Haendri, Pendidikan Agama di Indonesia (Jakarta: Puslitbang Pendidikan Agama dan Keagamaan, 2010), 154.
} 
characterized by impaired intellectual functions so that they appear to have social implications. ${ }^{20}$

The characteristics of children with intellectual disability are observed based on three primary developmental aspects, namely: 1) Cognitive function, which includes the ability to remember, understand, interpret, analyze, conclude, assess, speak, think logically, link one phenomenon with another, and so on; 2) Emotional, social and behavioral characteristics, in which children with intellectual disability have diverse characteristics; 3 ) Physical health of children with mild intellectual disability is similar to children in general in which they do not show any extraordinary medical conditions. However, their level of physical fitness is slightly below children in general. Under these conditions, collaborations between teachers and parents are fundamental. ${ }^{21}$

Similar to children in general, children with intellectual disability have assorted potentials and skills. Therefore, grouping is required for the basis of providing special education services. The classification is based on the severity of disability, namely: 1) Children with 'mild' intellectual disabilities are able to be educated, also known debil. In this group, the children may be able to function in the regular classroom but unable to adapt the curriculum optimally. They have I.Q.S in the 50-70 range; 2) Children with 'moderate' intellectual disabilities are able to be trained, also known as imbecil. They have I.Q.S in the 30-50 range. They are able to perform self-help and carry out social adaptations in their environment; 3) Children with 'severe' intellectual disabilities also known as idiot. These children have very low intelligence hence they are unable to perform neither self-help nor socialization. In general, they have physical weakness that is accompanied by paralysis. Very low general intelligence and emotional intelligence also inhibit them to control their emotions. Moreover, their personality does not function normally neither do their motor skills. ${ }^{22}$

Special education services for students with intellectual disability are an attempt to optimally stimulate the potential of these students. According to Hallahan and Kauffman in Mumpuniartri in the context of education services, intellectual disability is classified into mild and moderate in which:1) the services for mild group are similar to regular education in general, namely pre-school, primary, junior and senior secondary educational level. The students are able to communicate and interact with the group and to perform self-help with the supervision of teachers or parents;2) the services for moderate group entail the implementation of specific programs, i.e., speech therapy and physical therapy that oblige parents to actively participate in the programs. ${ }^{23}$ Instead of being oriented on academic achievement, they aremore functional and practicalfor everyday life. The emphasis of the programs is the independence and relationship of the students with their social environment. Two programs designed to achieve this purpose are self-help skills and vocational skills.

\section{Methods}

This study is an attempt to obtain comprehensive and in-depth information about the instructional methods applied by visually impaired teachers in teaching Students with intellectual disability in a public school for students with special

\footnotetext{
${ }^{20}$ Meria, "Model Pembelajaran Agama Islam bagi Anak Tunagrahita di SDLBYPPLB Padang Sumatra Barat," 55.

${ }^{21}$ Haendri, Pendidikan Agama di Indonesia, 156.

${ }^{22}$ Mumpuniatri, Pembelajaran Akademik Bagi Tunagrahita (Yogyakarta: -, 2010), 16.

${ }^{23} 16$.
} 
needs (sekolah luar biasa, SLB) in Sukoharjo, Central Java, Indonesia. This study is a descriptive qualitative research.

Primary data are collected through in-depth interview that involves the school principal, visually impaired teachers, homeroom teachers and teaching assistantsto obtain lucid information. Subsequently, observation is done to examine learning activities in which the subjects' behaviors, development and activities are recorded. For adding more information, documentation is done to collect and analyze necessary documents.

For data validation, triangulation technique is employed on research methods, sources and theories. Meanwhile, data analysis technique covers data reduction, data presentation and conclusion drawing.

\section{Result and Discussion}

Based on the result of this study, the Islamic religious education teachers with visual impairment employ several instructional methods in teaching students with mild and moderate intellectual disability. This study was carried out in Grade 8 of a public school for children with special needs $(S L B)$ in Sukoharjo. The methods include lecture, drill, storytelling, demonstration, and assignment methods. Instructional methods have a substantial role in teaching-learning process, including in Islamic religious education, since they will be adopted by the teachers in conveying the materials and guiding the learning process. The methods are detailed as follows:

\section{a. Lecture Method}

In conveying a subject matter to children with mild and moderate intellectual ability, teachers often use the lecture method due to its simplicity. The curriculum of Islamic religious education for SLB includes four aspects, namely the Qur'an and Hadith, Aqeedah Morals, Fiqh and Islamic History and Culture. In the introduction of these components, teachers frequently apply lecture method even though several methods are added based on the material. In the presentation, the teacher will explain a material and repeat it severally. For instance, for the theme of 99 Names of Allah, the teacher will give explanation twice for students with mild intellectual disability and three times in a meeting for students with moderate intellectual disability. With these repetitive explanations, the students are expected to understand the material.

Lecture method is a narrative method conducted by a teacher in the class. This method is the most commonly used due to its flexibility for any subjects. ${ }^{24}$ The majority of visually impaired teachers also prefer this method. In the present study, this method is also found to be implemented by Islamic religious education teacher with visually impairment in teaching students with both mild and moderate intellectual disability. They are required to attend the class directly and explain the material verbally. In using this methods, teacher are required to convey a material plainly with as simple as possible preference of language. It is vital since the intelligence of these students is below the average.

Lecture method is preferred by visually an impaired teacher with the consideration of the material is informative and general. It confirms he studies carried out by Hasan ${ }^{25}$ and Wulansari ${ }^{26}$ in which the majority of teachers

\footnotetext{
${ }^{24}$ Metodologi Pendidikan Agama Islam, 87.

${ }^{25}$ Hasan Yarmis, "Meningkatkan Keterampilan Vokasional Menanam Seledri melalui Metode Explicit Instruction pada Anak Tunagrahita Ringan," E-Jupekhu 1, no. 3 (n.d.): 7.

${ }^{26}$ Wulansari, "Pelaksanaan Pembelajaran Alat Musik Gitar Pada Anak Tunagrahita Kategori Ringan Tingkat SMALB," Jurnal Widia Ortodidaktika 8, no. 8 (2019): 789-803.
} 
introduce a materials with lecture method and assume it as an effective method to motivate students.

\section{b. Drill Method}

In teaching students with mild and moderate intellectual disability, drill method can be an option for helping students in understanding a material. This method is usually used when the students are required to memorize Short Surahs, i.e., Surah al-Quraish and Al-Lahab. The students are required to repeatthe surah several times, specifically 10 repetitions for students with mild intellectual disability and 12-15 repetitions for those with moderate intellectual disability. Meanwhile, the impaired visually teacher uses the Braille Qur'an.

The drill method as a strategy for students with mild and moderate intellectual disability in memorizing short surah is not delivered once but several times. With this method, the students are engaged in activities of training and exercise, leading them to improve their abilities and skills. The distinctive feature of this method is the activity of repeated iterations of the same thing $\mathrm{M} \mathrm{O} \mathrm{H} \mathrm{Bibit}$ Jaelani, "Metode Drill Bermedia Video Terhadap Keterampilan Bina Diri Anak Tunagrahita Ringan," JURNAL PENDIDIKAN KHUSUS 4, no. 1 (2014): 1-7..This method is frequently used by teachers of $S L B$ since it has been proven to be effective in training students with mild and moderate intellectual disability. It is linked to the characteristic of these students, i.e., slow learner, hence repetition is significantly required.

Likewise, Karli ${ }^{27}$ Andayani ${ }^{28}$ and Erlinda ${ }^{29}$ find out that drill method is able to improve the ability of understanding, memory and skills of students with mild and moderate intellectual disability. The implementation of this method is more effective with the supporting media and props as well as sophisticated simulative devices. ${ }^{30}$ Printed media are considered to be more useful in conveying particular information and themes due to their static features, emphasis on visual messages, and package of several texts, images and photos. ${ }^{31}$ In addition, audiovisual media such as videos are also useful for these students in memorizing surah.

\section{c. Storytelling Method}

Storytelling becomes a method employed for delivering the subject of Islamic religious education, particularly the Islamic History and Culture, in teaching the students of SBL in Sukoharjo, Central Java.In the class of mild intellectual disability, the visually impaired teacher presented the story of King Namrud and started the class by playing a film in front of the class. It is intended

\footnotetext{
${ }^{27}$ Karli, "Membaca dan Menulis untuk Anak Usia Dini melalui Aktivitas dan permainan yang menyenangkan," Jurnal Pendidikan Penabur 15, no. 1 (2010): 8.

${ }_{28}$ Andayani R, "Metode Drill Bermedia Flash Card Untuk Meningkatkan Pengetahuan dan Praktik Cuci Tangan Pakai Sabun pada Anak Tunagrahita," JHE Journal of Health Education 1, no. 1 (2016): 37-43, http://journal.unnes.ac.id/sju/index.php/jhealthedu.

${ }^{29}$ Erlinda Y, "Upaya Meningkatkan Hasil Belajar Matematika Perkalian Bersusun Kesamping Melalui Metode Drill Bagi Anak Tunagrahita Ringan," Jurnal Konseling Dan Pendidikan 4, no. 3 (2016): 1-18.

${ }^{30}$ Farhan, ngatio, and Annurahman, "Penggunaan Metode Driil Terhadap Hasil Belajar Matematika Hitung Campuran Kelas III SDN 24 Pontianak," Jurnal Pendidikan dan Pembelajaran Khatulistiwa 2, no. 3 (12AD): 14.

${ }^{31}$ Siti Zulaekhah, "Nutrition Education with Media Booklet on the Implementation of Nutrition Pack," Jurnal Kesehatan Masyarakat 7, no. 2 (2012): 130.
} 
to give initial insight for the students prior the storytelling method so they are not bored with the activity. Meanwhile, for students with moderate intellectual disability, the theme is the history of the Prophet Muhammad. In addition to storytelling method, the material of Islamic history is supported by film as the media.

Prior to the presentation, the visually impaired teacher learns the film from colleague. Thus, during the activity, the teacher who has known the storyline will be able to answer questions from students in relation with certain scenes of the film. Regarding the limitation of Islamic religious education teacher with visually impairment, the delivery of this material can be optimized through the sense of hearing with a meticulous technique.

Storytelling is a strategy of conveying a material through stories that is expected to attract the attention of students. In applying the lecture method in SLB Negeri Sukoharjo, the teacher uses film as the media for introducing the story of King Namrud and Prophet Muhammad to students with mild and moderate intellectual disability. It confirms Nana on the use of learning teaching that is proven to enhance the process and outcomes in accordance with students' level of thinking. ${ }^{32}$ Students with intellectual disability face difficulties in terms of abstraction hence concrete learning media are important to help them.

Storytelling is perceived to quite effective for students with both mild and moderate intellectual disability. Similarly, Diningtias ${ }^{33}$, and Riyanto ${ }^{34}$ conclude $^{2}$ that storytelling method and learning media are able to help students with intellectual disability in grasping a material. Likewise, Amalah suggest the effectiveness of this method as well. ${ }^{35}$

\section{d. Demonstration Method}

Demonstration is carried out to convey themes that require movement or process with detailed procedures. This method is applied in Figh. For students with mild and moderate intellectual disability, it covers the introduction of Call for Prayer (adhan) and Ablution (wudhu').

Prior to the demonstration, the teacher gives a brief explanation about the theory. Due to the relatively low intelligence of the students in which they are easily to forget and get bored, the teacher implements a demonstration method in front of the class. After the teacher gives demonstration, the students are required to immediately practice the steps. For instance, the procedures for ablution for students with moderate intellectual disability are being carried out in real, orderly manner by allowing the students practice directly, properly and correctly according to the guidelines exemplified by the teacher. Adhan for students with mild intellectual disability are done by appointing students to demonstrate it in front of the class.

Demonstration is a method that presents a topic by demonstrating and showing students about a particular process, situation or object, either actual

\footnotetext{
${ }^{32}$ Nana Sudjana, Media Pengajaran (Bandung: Sinar Baru Algesindo, 2010), 28.

${ }^{33}$ Diningtias Rintis and Mahmudah S, "Metode Bercerita Berbasis Media Gambar Berseri Terhadap Kemampuan Pengenalan Konsep Waktu pada Anak Tunagrahita Ringan," Jurnal Pendidikan Khusus 12, no. 03 (2019): 1-12.

${ }^{34}$ Rianto, Artanto F.D, and Edy, "Pengaruh Metode Pitcure And Pitcure Modifikasi Terhadap Keampuan Bercerita Anak Tunagrahita Ringan Di SLB Aisyah," Jurnal Pendidikan Khusus 5, no. 2 (2012): 1-14.

${ }^{35}$ Ayu Fatimatul Amalah and Siti Mahmudah, "Pengaruh Metode Bercerita Bermedia Pop Up Book Terhadap Kemampuan Berbicara Anak Tunagrahita SLB Al-Falah Sembayat Gresik," Jurnal Pendidikan Khusus 10, no. 2 (2018): 11.
} 
orsimulation. Even though the process merely requires the students to observe and pay attention, it presents learning material in a more concrete way. Through demonstration, students with intellectual disabilities have a chance to see, hear and eventually try the steps by themselves. It is able to substitute their short-term memory skills.

The demonstration of the call for prayer and ablution to students with mild and moderate intellectual disability is more effective. After the teacher demonstrates the steps in front of the class, the students are stimulated to perform in front of the class and allowed to practice ablution directly in the mosque. This method is fairly successfulas learning method for intellectual disabled students. According to Purwanti, this method is effective for students with mild intellectual disability. ${ }^{36}$ Similarly, Yusfidarwati verifies that it is able to improve the skills of students with mild intellectual disability. ${ }^{37}$

\section{e. Discussion Method}

In discussion activity, the teacher gives the opportunity for questions and answerssession, initiated by the teacher posing questions about the given material. This method is useful to provide a broad picture and to recall the material that has been taught to students.

The subject of Islamic religious education presented to students with mild and moderate intellectual disabilityalways entails discussion method hence the teacher is able to figure out the extent to which students understand the material. In conveying the 99 Names of Allah (Al Asma UI Husna), for instance, the teacher initially explainsit and is accompanied by the feedback between teachers and students. The teacher posed question to the students but only two students with communication skills who responded it. During the theme of morals on mild intellectual disability class, the teacher commenced it by giving explanation and simple examples, which wasfollowed by posing a question to each student. Since the students had problems in answering the questions, the teacher re-explained the material.

Discussion is a method that involves the active participation of both teachers and students in which teacher poses questions and students answer those questions. Based on the observation, the Islamic religious teachers frequently posed questions about the given material. In this context, the teachers are able to recognize to what extent the students understand the given material. Nevertheless, discussion method promotes teacher-centered activity since the teachers are more active in the learning process while the students are relatively passive.

The finding of this study reaffirms Oktarina, emphasizing discussion as an acceptable, proper instructional method. In fact, when the teacher poses a question, the students tend to respond it even though with short and unrelated answer. In general, students with intellectual disability have limited vocabulary thus this method will motivate the students to have courage in speaking in front of the class.

\section{f. Assignment Method}

Assignment method is given only to students with mild intellectual disability by considering their abilities in writing, reading and performing simple counting.

\footnotetext{
${ }^{36}$ Endang Purwati, "Meningkatkan Ketrampilan Membuat Peyek Rinuak Melalui Metode Demontrasi Pada Anak Tunagrahita Ringan.," E-Jupekhu 4, no. 1 (n.d.): 72-84.

${ }^{37}$ Yusfidarwati, "Meningkatkan Keterampilan Memotong Kuku Melalui Metode Demonstrasi Bagi Anak Tunagrahita Ringan," IImiah 1, no. 1 (2012): 264.
} 
For instance, on the topic of the Al Asma UI Husna, the teacher distributed a printed copy of the 99 Names of Allah and ordered the students to write it on their notebook. After completing the assignment, the teacher instructed one of the students to collect the notebook for assessment. To ensure their understanding, the teacher appointed a student to write down the Names of Allah on the board and asking the class whether the Names written on the board were correct.

The learning activities carried out students with mild and moderate intellectual disability are guided by visually impaired teachers without any special educational background. Nevertheless, the teacher has recognized the characters of each student, both with mild and moderate intellectual disability. When the teacher has problems in controlling several students, the teacher will give a distraction to calm the student down. In handling the class, the teacher has no assistance from colleague but from self-helped students. The activities in the classroom is designed non-monotonous, both the material and strategies are delivered with particular tricks in the learning process in the classroom with practical joke interlude. It is an attempt to prevent the students who easily get bored.

Islamic religious education for intellectually disabled children is also devised based on the needs of students in real life in order to include education as a learning target. The objective is to facilitate students in acquiring certain knowledge, skills and attitudes based on the teachings of Islam. Assignment method is intended as an evaluation to find out to what extent the students are able to comprehend specific materials as well as to foster learning skills, independence and responsibilities. This method is only applied in mild intellectual disability class with the consideration they are able to write, read and perform simple counting. The teacher gives assignment in the form of printouts and requires the students to re-write them down.

Similar to the findings of this study, Oktarina ${ }^{38}$ and Sefni ${ }^{39}$ claim that assignment method will reveal the capacity of the students in understanding the material and assess the effectiveness of the method. Febriana dan Wiwik Widajati Wahyuningtyas, "Penerapan Metode Resitasi Berbasis Android Terhadap Perilaku Sosial Pada Anak Tunagrahita Ringan," JURNAL PENDIDIKAN KHUSUS 12, no. 3 (2019): 1-17. also suggests the implementation of assignment method in encouraging students to socialize with the surroundings. ${ }^{40}$

Employing selected instructional methods, the visually impaired teacher is supported by learning media, screen reader technology and printouts. In fact, the activity is carried out by the teacher without any assistant or colleague, but with the help of self-helped students with good communication skills.

\section{Conclusion}

In guiding learning activities, visually impaired teachers implement several instructional methods, including lecture method, storytelling method, discussion

\footnotetext{
${ }^{38}$ Fipta Oktorina, "Pendidikan Agama Islam Pada Anak Tunagrahita Di SDLB Negeri Bengkulu Tahun Pelajaran 2017-2018," At-Ta'lim 17, no. 1 (2018): 81-94, https://ejournal.iainbengkulu.ac.id/index.php/attalim/article/view/1182.

39 Sefni F, "Efektifitas Metode Proyek Pada Pembelajaran Ketrampilan Bagi Anak Tunagrahita Sedang Kelas X SMALB DI YPAC Sumber," Jurnal IImiah Pendidikan Khusus 3, no. 3 (2014): 221-29, https://doi.org/10.24036/jupe38440.64.

${ }^{40}$ Febriana dan Wiwik Widajati Wahyuningtyas, "Penerapan Metode Resitasi Berbasis Android Terhadap Perilaku Sosial Pada Anak Tunagrahita Ringan," JURNAL PENDIDIKAN KHUSUS 12, no. 3 (2019): 1-17.
} 
method, drill method, demonstration method and assignment method. In teaching the students with mild and moderate intellectual disability, the teacher always employs audio-visual media and images equipped with screen reader technology, the Braille Qur'an and printouts. With the absence of colleague or assistant, the visually impaired teacher is assisted by the assistance of self-helped and communicative students particularly in preparing learning media, distributing printouts and reading the worksheets of other students.

\section{References}

Amalah, Ayu Fatimatul, and Siti Mahmudah. "Pengaruh Metode Bercerita Bermedia Pop Up Book Terhadap Kemampuan Berbicara Anak Tunagrahita SLB Al-Falah Sembayat Gresik." Jurnal Pendidikan Khusus 10, no. 2 (2018).

Chea, Hwee kok Noel, and Ee Meng wong. "From Mental Retardation to Intellectual Disability: A Proposed Educological Framework for Teaching Students with Intellectual Disabilities in Singapore." Academic Research International 5, no. 03 (2014).

Chikurinji, Takeshi. "A Study on Teaching Schoolchildren with Intellectual Disability." NISE Bulletin, November 2008, 9 edition.

Effendi, Muhammad. Pengantar Psikopedagogik Anak Berkelainan. Yogyakarta: Ombak, 2006.

F, Sefni. "Efektifitas Metode Proyek Pada Pembelajaran Ketrampilan Bagi Anak Tunagrahita Sedang Kelas X SMALB DI YPAC Sumber." Jurnal IImiah Pendidikan Khusus 3, no. 3 (2014): 221-29. https://doi.org/10.24036/jupe38440.64.

Farhan, ngatio, and Annurahman. "Penggunaan Metode Driil Terhadap Hasil Belajar Matematika Hitung Campuran Kelas III SDN 24 Pontianak." Jurnal Pendidikan dan Pembelajaran Khatulistiwa 2, no. 3 (12AD).

Haendri, Amin Muhammad. Pendidikan Agama di Indonesia. Jakarta: Puslitbang Pendidikan Agama dan Keagamaan, 2010.

Ismail. Strategi Pembelajaran Agama Islam Berbasis PAIKEM. Semarang: Rasail Media Group, 2012.

Jaelani, M O H Bibit. "Metode Drill Bermedia Video Terhadap Keterampilan Bina Diri Anak Tunagrahita Ringan." JURNAL PENDIDIKAN KHUSUS 4, no. 1 (2014): 1-7.

Karli. "Membaca dan Menulis untuk Anak Usia Dini melalui Aktivitas dan permainan yang menyenangkan." Jurnal Pendidikan Penabur 15, no. 1 (2010).

Kemis, and Ati Rosnawati. Pendidikan Anak Berkebutuhan Khusus Tunagrahita. Luxima Metro Media, 2013.

Kumalasari, Intan, and Darliana Sormin. "Metode Pembelajaran Pendidikan Agama Islam Pada Anak Tunagrahita Di SLB C Muzdalifah Medan." Tazkir: JUrnal Penelitian LImu- IImu Sosial Dan Keislaman 05, no. 01 (2019).

Maftuhin, M, and Januar Fuad. "Pembelajaran Pendidikan Agama Islam Pada Anak Berkebutuhan Khusus." Jurnal An-Nafs: Kajian Penelitian Psikologi 03, no. 01 (2018).

Mardhiyah, Siti Dawiyath, and Jasminto. "Identifikasi anak berkebutuhan khusus dan strategi pembelajarannya." Al-Ta'dib 3, no. 01 (2013). 
Mardiyanti, N, and Luh Putu Suta Haryanthi. "Challenges on learning Islam among deaf Muslim in an Indonesian context: Deaf teachers perspective." International Medical Journal Malaysia, no. specialissue1 (2016).

Meria, Azizah. "Model Pembelajaran Agama Islam bagi Anak Tunagrahita di SDLBYPPLB Padang Sumatra Barat." Tsaqafah 11, no. 2 (2015): 54-62. https://doi.org/10.21111/tsaqafah.v11i2.273.

Mumpuniatri. Pembelajaran Akademik Bagi Tunagrahita. Yogyakarta: -, 2010.

Mutmainnah, Rahmita Nurul. "Pemahaman Siswa Tunanetra (Buta Total Sejak Lahir Dan Sejak Waktu Tertentu) Terhadap Bangun Datar Segitiga." Jurnal Pendidikan Matematika dan Matematika 01, no. 01 (2015).

Oktorina, Fipta. "Pendidikan Agama Islam Pada Anak Tunagrahita Di SDLB Negeri Bengkulu Tahun Pelajaran 2017-2018." At-Ta'lim 17, no. 1 (2018): 81-94.

https://ejournal.iainbengkulu.ac.id/index.php/attalim/article/view/1182.

Purwati, Endang. "Meningkatkan Ketrampilan Membuat Peyek Rinuak Melalui Metode Demontrasi Pada Anak Tunagrahita Ringan." E-Jupekhu 4, no. 1 (n.d.): 72-84.

$\mathrm{R}$, Andayani. "Metode Drill Bermedia Flash Card Untuk Meningkatkan Pengetahuan dan Praktik Cuci Tangan Pakai Sabun pada Anak Tunagrahita." JHE Journal of Health Education 1, no. 1 (2016): 37-43. http://journal.unnes.ac.id/sju/index.php/jhealthedu.

Rachmah, khosiah siti, and Rika Sa'diyah. "Strategi Pembelajaran PAI Pada Peserta Didik Tuna Grahita Sekolah Dasar Kelas Awal Di Sekolah Dasar Luar Biasa (SDLB) Pembina Tingkat I Cilandak Lebak- Bulus Jakarta Selatan." JUrnal Pandidikan Islam 2, no. 01 (2017).

Ramayulis. Metodologi Pendidikan Agama Islam. R.J. Offset. ed. Jakarta: Kalam Mulia, 2014.

Rianto, Artanto F.D, and Edy. "Pengaruh Metode Pitcure And Pitcure Modifikasi Terhadap Keampuan Bercerita Anak Tunagrahita Ringan Di SLB Aisyah." Jurnal Pendidikan Khusus 5, no. 2 (2012): 1-14.

Rintis, Diningtias, and Mahmudah S. "Metode Bercerita Berbasis Media Gambar Berseri Terhadap Kemampuan Pengenalan Konsep Waktu pada Anak

Tunagrahita Ringan." Jurnal Pendidikan Khusus 12, no. 03 (2019): 1-12.

Somantri, Sujhati. Psikologi Anak Luar Biasa. Bandung: Refika Aditama, 2012.

Sudjana, Nana. Media Pengajaran. Bandung: Sinar Baru Algesindo, 2010.

Sulthon. "Pola Keberagamaan Kaum Tuna Netra Dan Dampak Psikologis Terhadap Penerimaan Diri." Quality 4, no. 01 (2016).

Wahyuningtyas, Febriana dan Wiwik Widajati. "Penerapan Metode Resitasi Berbasis Android Terhadap Perilaku Sosial Pada Anak Tunagrahita Ringan." JURNAL PENDIDIKAN KHUSUS 12, no. 3 (2019): 1-17.

Wiyani, Adi Novan. Pendidikan Karakter berbasis Iman dan Taqwa. Yogyakarta: Teras, 2012.

Wulansari. "Pelaksanaan Pembelajaran Alat Musik Gitar Pada Anak Tunagrahita Kategori Ringan Tingkat SMALB." Jurnal Widia Ortodidaktika 8, no. 8 (2019).

Y, Erlinda. "Upaya Meningkatkan Hasil Belajar Matematika Perkalian Bersusun Kesamping Melalui Metode Drill Bagi Anak Tunagrahita Ringan." Jurnal Konseling Dan Pendidikan 4, no. 3 (2016): 1-18.

Yarmis, Hasan. "Meningkatkan Keterampilan Vokasional Menanam Seledri melalui Metode Explicit Instruction pada Anak Tunagrahita Ringan." EJupekhu 1, no. 3 (n.d.): 2009.

Yusfidarwati. "Meningkatkan Keterampilan Memotong Kuku Melalui Metode Demonstrasi Bagi Anak Tunagrahita Ringan." IImiah 1, no. 1 (2012). 
Oktaviana Saputri, Hakiman, Suluri

Zulaekhah, Siti. "Nutrition Education with Media Booklet on the Implementation of Nutrition Pack." Jurnal Kesehatan Masyarakat 7, no. 2 (2012). 